\title{
PODSTAWOWE ZAŁOŻENIA REFORMY EUROPEJSKIEGO PRAWA FINANSOWEGO SŁUŻĄCE OGRANICZANIU WZROSTU DŁUGU I DEFICYTU PUBLICZNEGO
}

\begin{abstract}
WSTĘP
W opracowaniu poddano analizie projektowane zmiany w europejskim prawie finansowym, których celem jest przywrócenie i kontrola równowagi finansów publicznych państw Unii Europejskiej. Problem narastającego długu i deficytu publicznego w poszczególnych państwach $\mathrm{UE}^{1}$ spowodował konieczność zrewidowania dotychczasowych oraz poszukiwania nowych regulacji, służących wzmocnieniu kontroli nad poziomem deficytu i długu publicznego, tempem ich wzrostu i przyczynami tego zjawiska ${ }^{2}$. W związku z tym na szczeblu UE, w tym szczególnie w państwach Unii Gospodarczej i Walutowej (dalej UGW) ma zostać wdrożona reforma zarządzania gospodarczego, której elementem są także unormowania związane $z$ wzmocnieniem środków nadzoru nad polityką budżetową państw UE. Należą do nich m.in. rygorystyczna konsolidacja budżetowa, wzmocnienie Paktu Stabilności i Wzrostu ${ }^{3}$ (dalej PSW), wprowadzenie tzw. Semestru

1 Tytułem przykładu można wskazać, że w okresie 2008-2009 r. deficyt publiczny w relacji do PKB np. w Irlandii wzrósł prawie dwukrotnie ( 7,3 do 14,4\% PKB), a w Portugalii prawie trzykrotnie (z 2,9 do 9,3\% PKB), „PF - Monitor konwergencji nominalnej w UE 27”, Ministerstwo Finansów 2011, nr 3, http://www.mf.gov.pl/index.php?const=1\&dzial=2912\&wysw=83\&sub=sub4 (data dostępu: 02.04.2011 r.), s. 4.

2 Z uwagi na ramy objętościowe opracowania pominięto w nim rozważania dotyczące instytucjonalnych zmian związanych $\mathrm{z}$ konstruowaniem mechanizmu wsparcia finansowego dla państw UE, które dotyczą powołania tzw. Europejskiego Mechanizmu Stabilizacyjnego.

3 Pakt Stabilności i Wzrostu tworzą regulacje: rozporządzenia Rady (WE) z dnia 7 lipca 1997 r. $\mathrm{nr} 1467 / 97 \mathrm{w}$ sprawie przyspieszenia i wyjaśnienia procedury nadmiernego deficytu (Dz. Urz. UE L z 1997/209/6 ze zmianami: Dz. Urz. UE - sp.10/1/89, Dz. Urz. UE L z 2005/174/5), rozporządzenia Rady (WE) z dnia 7 lipca 1997 r. nr 1466/97 mające na celu wzmocnienie nadzoru nad sytuacją
\end{abstract}


Europejskiego, doprecyzowanie kryterium fiskalnego długu publicznego ujętego w Traktacie o Funkcjonowaniu Unii Europejskiej ${ }^{4}$ (dalej TofUE), uwzględnianie w większym zakresie czynników wpływających na poziom kwoty długu publicznego, w tym szczególnie deficytu publicznego.

Niewątpliwie przyczyny analizowanej reformy europejskiego prawa finansowego mają przede wszystkim charakter ekonomiczny, w postaci znacznego wzrostu deficytu i długu publicznego w państwach UE, który zagraża stabilności finansowej oraz gospodarczej całej UE, w tym szczególnie UGW. Sytuacja taka wywołała konieczność podjęcia określonych środków zaradczych również o charakterze normatywnym. Dlatego też na szczeblu UE podejmowane są w tym zakresie także działania antykryzysowe, które zmierzają do zmniejszenia tempa wzrostu deficytu i długu publicznego przez wzmocnienie prawnych instrumentów służących temu celowi. Planowane zmiany legislacyjne mają charakter kompleksowy. Odnoszą się on bowiem nie tylko do kontroli poziomu oraz tempa wzrostu deficytu i długu publicznego w państwach UE, ale także uwzględniają kontekst makroekonomiczny tego problemu. Silniejszy ma być bowiem także nadzór nad polityką makroekonomiczną państw UE. W konsekwencji wzmocnione mają zostać ramy instytucjonalne zarządzania gospodarczego w UE, co pozwoli na skuteczniejsze podejmowania działan antykryzysowych oraz powinno zmniejszyć ryzyko wystąpienia zjawisk kryzysowych w przyszłości.

\section{PODSTAWOWE REGULACJE EUROPEJSKIEGO PRAWA FINANSOWEGO DOTYCZĄCE DŁUGU I DEFICYTU PUBLICZNEGO - STAN AKTUALNY}

Postawę prawną prowadzenia przez państwa UE rozważnej polityki budżetowej stanowi art. 126 TofUE, w którym nakazano państwom UE unikanie nadmiernego deficytu publicznego, a także określono zasady stosowania tzw. procedury nadmiernego deficytu (Excessive Deficit Procedure). W protokole w sprawie procedury dotyczącej nadmiernego deficytu (załączonym do TofUE) określono fiskalne kryteria konwergencji, który wynoszą odpowiednio: $3 \%$ dla stosunku planowanego lub rzeczywistego deficytu publicznego do PKB oraz 60\% dla stosunku długu publicznego do PKB. Ustalona w TofUE wysokość fiskalnych kryteriów konwergencji dotyczących długu i deficytu publicznego nie ma charakteru kate-

budżetową oraz nadzór i koordynację polityk gospodarczych (Dz. Urz. UE L 209 z 2/8/1997) oraz uchwały Rady Europejskiej z dnia 17 czerwca 1997 r. (Dz. Urz. UE C 236 z 2/8/1997).

4 Traktat o funkcjonowaniu Unii Europejskiej - wersja skonsolidowana (Dz. Urz. UE C 115 z 9.5.2005 r., s. 47). 
gorycznego, ponieważ przy ich przekroczeniu przez państwo UE uwzględnia się m.in. przesłanki o charakterze koniunkturalnym. W art. 2 ust. 1 rozporządzenia Rady nr 1467/1997 ustalono czynniki powodujące, że przekroczenie przez deficyt publiczny poziomu 3\% PKB uznaje się za wyjątkowe i tymczasowe (m.in. znaczne pogorszenie koniunktury gospodarczej ${ }^{5}$ ). W związku z tym przy ocenie i podjęciu decyzji, czy w danym państwie UE istnieje nadmierny deficyt, Komisja i Rada mogą uznać, że jest on wynikiem poważnego pogorszenia koniunktury, które ma charakter wyjątkowy, tzn. przekroczenie kryterium fiskalnego deficytu publicznego jest następstwem ujemnego rocznego tempa wzrostu PKB lub skumulowanego spadku produkcji podczas przedłużającego się okresu bardzo niskiego wzrostu PKB w stosunku do potencjalnego wzrostu. W tzw. części prewencyjnej PSW wprowadzono obowiązek przygotowywania przez państwa UE programów konwergencji oraz ich aktualizacji. W tym celu państwa UE powinny ustalić średnioterminowy cel budżetowy (Medium-term objective). W związku z tym w rozporządzeniu Rady nr 1466/97 określono, że każde państwo członkowskie UE może posiadać odmienny średnioterminowy cel budżetowy, który może odbiegać od wymogu pozycji budżetowej bliskiej równowadze lub nadwyżce. Dlatego też średnioterminowy cel budżetowy danego państwa UE jest ustalany z pewnym marginesem zabezpieczającym przed przekroczeniem przez sektor instytucji rządowych i samorządowych (general government) kryterium fiskalnego deficytu publicznego 3\% PKB. Natomiast procedura nadmiernego deficytu stanowi tzw. część naprawczą PSW, której zasady doprecyzowano w rozporządzeniu Rady nr 1467/97. Osiągnięcie średnioterminowego celu budżetowego przez dane państwo UE ma przyczynić się do zagwarantowania pewnego stopnia bezpieczeństwa przy wypełnianiu wartości referencyjnej 3\% PKB dla deficytu publicznego, a także zapewnienia szybkiej poprawy przy osiąganiu równowagi fiskalnej z jednoczesnym pozostawieniem elastyczności w zakresie polityki fiskalnej przy realizacji obu tych założeń ${ }^{6}$.

Należy również wskazać, że niezależnie od nakazu unikania nadmiernego deficytu publicznego państwa UE mają obowiązek koordynacji swoich polityk gospodarczych (art. 121 TofUE).

5 W art. 2 ust. 1 rozporządzenia Rady nr 1467/97 ustalono również przesłanki okresowego przekroczenia przez deficyt publiczny wartości odniesienia wynoszącej 3\% PKB. Sytuacja taka następuje, jeżeli prognozy budżetowe dostarczone przez Komisję wskazują, że deficyt spadnie poniżej wartości bazowej po zakończeniu nadzwyczajnego zdarzenia lub znacznego pogorszenia koniunktury.

B. Jajko, Dtug publiczny a równowaga fiskalna, Warszawa 2008, s. 54. 


\section{WPROWADZENIE TZW. SEMESTRU EUROPEJSKIEGO*}

Planowane zmiany legislacyjne w europejskim prawie finansowym związane są ze strategią Europa 2020, w której określono przesłanki osiągnięcia długotrwałego wzrostu gospodarczego i wyjścia z kryzysu gospodarczego przez UE. Należy do nich: wprowadzenie średnio- i długoterminowych reform, które doprowadzą do zrównoważenia finansów publicznych i zwiększenia potencjału wzrostu gospodarczego poszczególnych państw UE. W tym celu planuje się również wprowadzenie zmian legislacyjnych służących trwałej konsolidacji budżetowej państw UE oraz koordynacji polityk gospodarczych w UGW. Konsolidacja budżetowa powinna rozpocząć się w 2011 i zakończyć w 2013 r. obniżeniem deficytu publicznego w państwach UE poniżej wartości odniesienia 3\% PKB. Koordynacji w strefie euro ma także służyć stworzenie ram prawnych dla dokładniejszego i pełniejszego nadzoru na państwami UGW w celu poprawienia dyscypliny budżetowej jej państw członkowskich, a także objęcia nadzorem gospodarczym również nierównowagi makroekonomicznej. Ponadto zmiany te mają stworzyć podstawy do działań podejmowanych przez UGW jako całość, zmierzających do usuwania niestabilności finansowej całej strefy euro ${ }^{7}$.

Pierwszym obszarem zmian legislacyjnych jest wzmocnienie prewencyjnej części PSW przez wprowadzenie tzw. Semestru Europejskiego, który ma być mechanizmem zintegrowanego ekonomicznego nadzoru gospodarczego i zarządzania na szczeblu UE, służącym koordynacji polityk budżetowych w UE oraz $\mathrm{w}$ strefie euro, dokonywanym ex ante, $\mathrm{z}$ uwzględnieniem regulacji PSW oraz założeń strategii Europa 2020. Mechanizm ten obejmuje 6-miesięczny cykl uzgodnień, który rozpoczyna się w styczniu danego roku (po raz pierwszy w 2011 r.) $)^{8}$. Pierwszym jego etapem jest opublikowanie przez Komisję rocznego planu wzrostu gospodarczego (Annual Growth Survey), który będzie przedmiotem dyskusji na forum Parlamentu Europejskiego przed wiosennym posiedzeniem Rady Europejskiej w marcu danego roku. Po raz pierwszy dokument ten został wydany w styczniu 2011 r. $^{9}$ Określono w nim zasady rygorystycznej konsolidacji budżetowej w państwach UE. Jej rygoryzm przejawia się w konieczności corocz-

* Semestr Europejski został doprecyzowany w regulacjach europejskiego prawa finansowego omówionego w dalszej części opracowania.

Komunikat Komisji Europa 2020, Strategia na rzecz inteligentnego i zrównoważonego rozwoju sprzyjającego wtaczeniu spotecznemu, Bruksela, 3.3.2010 KOM(2010) 2020, s. 29 i n.

8 Europeansemester: a new architecture for the new EUEconomic governance, MEMO/11/14,Brussels, 12.01.2011, www.ec.europa.eu/europe2020/pdf/m11_14.en.pdf (data dostępu: 20.03.2011 r.), s. 1 i n.

9 Komunikat Komisji do Parlamentu Europejskiego, Rady, Europejskiego Komitetu Ekonomiczno-Spotecznego i Komitetu Regionów, Roczna wizja wzrostu gospodarczego: wsparcie catóściowej odpowiedzi UE na kryzys, Bruksela, 12.01.2011 r. 
nej korekty bilansu budżetu strukturalnego o więcej niż 0,5\% PKB. W ocenie Komisji mniejsza korekta nie jest bowiem wystarczająca, aby obniżyć poziom długu publicznego do relacji 60\% w stosunku do $\mathrm{PKB}^{10}$. Instrumentem służącym rygorystycznej konsolidacji mają być również udoskonalone numeryczne reguły fiskalne (numerical fiscal rules) zaproponowane przez Komisję. Ponadto państwa członkowskie UE, w tym szczególnie te, które są objęte procedurą nadmiernego deficytu (a więc także i Polska), powinny m.in. z ostrożnością określać prognozy wzrostu dochodów i wydatków ujęte w programach konwergencji, w niektórych wypadkach dokonać podwyżki podatków pośrednich ${ }^{11}$.

Kolejnym etapem działań podejmowanych w ramach Semestru Europejskiego jest dokonywana na wiosnę przez Radę i państwa UE identyfikacja głównych wyzwań stojących przez UE. Podstawą do tego jest przedstawiony w styczniu roczny plan wzrostu gospodarczego. Następnie państwa UE, uwzględniając te wytyczne, prezentują swoje średniookresowe strategie budżetowe ujęte w krajowych programach konwergencji oraz sporządzają krajowe programy reform, w których określają działania, jakie zostaną podjęte $\mathrm{w}$ takich obszarach, jak np. zatrudnienie, badania. Oba te dokumenty zostaną przesłane Komisji do końca kwietnia danego roku celem ich oceny. Na podstawie oceny tych dokumentów, dokonanej przez Komisję, Rada wyda w czerwcu i lipcu danego roku wytyczne dla każdego państwa. W lipcu, przed zakończeniem w państwach UE procedury budżetowej, kierowane będą do każdego państwa zalecenia wynikające $z$ wcześniejszej oceny programów konwergencji i krajowych programów reform ${ }^{12}$.

\section{UNORMOWANIA SŁUŻĄCE WZMOCNIENIU PAKTU STABILNOŚCI I WZROSTU ORAZ NADZORU BUDŻETOWEGO W STREFIE EURO}

Planowane zmiany europejskiego prawa finansowego zmierzają również do wzmocnienia PSW. W zakresie części prewencyjnej PSW celem tych zmian

10 Wskazuje się, że dopiero wprowadzenie przez państwa UE w ciągu najbliższych 20 lat korekty salda budżetu strukturalnego na corocznym poziomie 1\% PKB lub wyższej rocznie pozwoli osiągnąć trwałą tendencję spadkową w zakresie poziomu długu publicznego wyrażonego jako odsetek PKB, Roczne sprawozdanie gospodarcze. Zatacznik 2. Sprawozdanie makroekonomiczne, $\mathrm{KOM}(2011)$ 11, Bruksela 12.01.2011r., s. 13. Obniżenie poziomu długu publicznego do 60\% PKB jest uzasadnione nie tylko ustaleniem na tym poziomie fiskalnego kryterium konwergencji dotyczącego długu publicznego, lecz również zasadą bezpiecznego poziomu tego długu przyjętą w finansach publicznych - tj. wynoszącą 40\% PKB. Por. K. Marchewka-Bartkowiak, Problem dtugu publicznego w Unii Europejskiej ze szczególnym uwzględnieniem kryteriów z Maastricht, [w:] Polityka budżetowa, red. G. Gołębiowski, Studia Biura Analiz Sejmowych, Warszawa 2010, nr 3, s. 195.

11 Komunikat Komisji do Parlamentu Europejskiego, Rady, Europejskiego Komitetu, s. 4 i n.

12 European semester: a new architecture, s. 2 i n. 
jest wzmocnienie kontroli nad prowadzeniem przez państwa UE rozważnej polityki budżetowej, tak aby nie dopuścić do nierównowagi w finansach publicznych poszczególnych państw UE. Służyć ma temu zmiana rozporządzenia Rady nr 1466/97 ${ }^{13}$ dotycząca wprowadzenia nowej zasady rozważnej polityki budżetowej, która ma przeciwdziałać przeznaczaniu nadzwyczajnych dochodów publicznych na cele inne niż spłata długu publicznego. Zasada ta ma przejawiać się w określeniu, że

roczny wzrost wydatków nie powinien przekraczać ostrożnie ustalonego tempa wzrostu PKB w średnim okresie lub powinien być od niego wyraźnie niższy w sytuacji, gdy średniookresowy cel budżetowy nie został osiągnięty, chyba że średniookresowy cel budżetowy został zrealizowany z dużą nawiązką lub nadwyżce wzrostu wydatków ponad ostrożnie ustalone tempo wzrostu $\mathrm{w}$ średnim okresie towarzyszą odpowiednie środki uznaniowe po stronie dochodów ${ }^{14}$.

W zmienionym rozporządzeniu Rady nr 1466/97 zdefiniowano kryteria decydujące o tym, czy polityka budżetowa jest rozważna w rozumieniu tego aktu. Oceny ostrożnie ustalonego tempa wzrostu dokonuje się na podstawie 10-letnich prognoz, aktualizowanych w regularnych odstępach czasu. Ustalono także sankcje w przypadku znacznego odstąpienia przez państwo UE od rozważnej polityki budżetowej (ostrzeżenie, zalecenie w sprawie podjęcia niezbędnych środków dostosowawczych).

W ramach części naprawczej PSW zmienione ma zostać rozporządzenie nr 1467/97 15 . Zmiany zmierzają do poprawy kryterium długu publicznego w procedurze nadmiernego deficytu. W tym celu ma zostać przyjęta liczbowa wartość referencyjna (numerical benchmark), która pozwoli ocenić, czy relacja długu do $\mathrm{PKB}$, przekraczająca $60 \% \mathrm{PKB}$, obniża się w zadowalającym tempie, tj. jeżeli w ciągu ostatnich 3 lat dystans względem wartości referencyjnej wynoszącej $60 \%$ PKB zmniejsza się w tempie 1/20 rocznie. Nawet jeżeli warunek ten nie zostanie spełniony, nie oznacza to automatycznego wszczęcia procedury nadmiernego deficytu, ponieważ przy jej podjęciu uwzględniane mają być m.in. czynniki wpływające na wysokość długu publicznego, w tym też ryzyka związane $\mathrm{z}$ jego strukturą (np. ukryte zobowiązania związane ze starzeniem się społeczeństwa) ${ }^{16}$.

13 Wniosek Rozporzqdzenie Parlamentu Europejskiego i Rady zmieniajace rozporzqdzenie (WE) nr 1466/97 w sprawie wzmocnienia nadzoru pozycji budzetowych oraz nadzoru $i$ koordynacji polityk gospodarczych, $\mathrm{KOM}(2010)$ 526, Bruksela, 29.09.2010 r.

14 Ibidem, s. 4.

15 Wniosek Rozporzqdzenie Rady zmieniajace rozporzadzenie (WE) nr 1467/97 w sprawie przyspieszenia i wyjaśnienia procedury nadmiernego deficytu, $\mathrm{KOM}(2010)$ 522, Bruksela, 29.09.2010 r.

16 Ibidem, s. 5 i n. 
Wzmocnieniu egzekwowania od państw strefy euro nowych wymogów związanych z częścią prewencyjną i naprawczą PSW mają służyć nowe sankcje ujęte $\mathrm{w}$ ramach nadzoru budżetowego ${ }^{17}$. W projektowanym rozporządzeniu na państwo strefy euro, w stosunku do którego podjęto decyzję o nadmiernym deficycie, wcześniej niż dotychczas ma być nałożona sankcja w postaci obowiązku złożenia nieoprocentowanego depozytu w wysokości 0,2\% PKB. Jeżeli państwo takie nie zastosowałoby się do zalecenia skorygowania swojego deficytu publicznego, depozyt ten przekształcałby się $\mathrm{w}$ grzywnę, a w razie dalszego braku stosownej korekty deficytu publicznego stosowane byłyby sankcje ujęte już aktualnie w PSW ${ }^{18}$.

\section{KRAJOWE RAMY BUDŻETOWE I NUMERYCZNE REGUŁY FISKALNE}

W związku z koniecznością koordynowania polityki budżetowej w poszczególnych państwach UGW proponuje się wprowadzenie ram instytucjonalnych dotyczących zarządzania budżetowego w danym państwie, które mają sprzyjać zwiększeniu przejrzystości i kontroli nad przebiegiem procesów budżetowych. W art. 2 projektowanej dyrektywy ${ }^{19}$ zdefiniowano ramy budżetowe, które obejmują zbiór uzgodnień, procedur i instytucji stanowiących podstawę prowadzenia polityki budżetowej sektora general government, w szczególności systemy rachunkowości budżetowej i sprawozdawczości statystycznej, numeryczne reguły fiskalne nakładające na politykę budżetową trwałe ograniczenia, wyrażone zbiorczymi wskaźnikami wyników budżetowych, takimi jak m.in. deficyt sektora publicznego, jego potrzeby pożyczkowe lub dług publiczny. W kolejnych przepisach projektowanej dyrektywy (art. 3-13) określono szczegółowe zasady realizowania poszczególnych elementów tworzących ramy budżetowe. Wynikają z nich obowiązki dotyczące m.in. udostępniania danych statystycznych sektora general government, rzetelności sporządzanych prognoz makroekonomicznych i budżetowych, zasad wyznaczania numerycznych reguł fiskalnych oraz ich uwzględniania przy uchwalaniu krajowej ustawy budżetowej, przyjęcia średniookresowych ram budżetowych w horyzoncie 3-letnim oraz wieloletniego planowania finansowego i zasad przejrzystości sektora finansów publicznych.

Wzmocnienie średnioterminowych ram budżetowych dodatkowym instrumentem w postaci numerycznych reguł fiskalnych na szczeblu krajowym należy ocenić pozytywnie, szczególnie że ich range podkreśla ujęcie w projektowanej

17 Wniosek Rozporzqdzenie Parlamentu Europejskiego i Rady w sprawie skutecznego egzekwowania nadzoru budżetowego w strefie euro, $\operatorname{KOM(2010)~524,~Bruksela,~29.09.2010~r.~}$

18 Ibidem, s. 6 i n.

19 Wniosek Dyrektywa Rady w sprawie wymogów dotyczacych ram budizetowych w pañstwach cztonkowskich, $\operatorname{KOM(2010)~523,~Bruksela,~29.09.2010~r.,~s.~} 7$. 
dyrektywie $\operatorname{Rady}^{20}$. W piśmiennictwie podkreśla się, że w przypadku krajowych reguł fiskalnych ujęcie jej w akcie normatywnych odpowiedniej rangi (ustawa, konstytucja) zwiększa ich stabilność i utrudnia zmianę pod wpływem czynników o charakterze politycznym. Państwa UGW mają ponadnarodowe reguły fiskalne $\mathrm{w}$ postaci fiskalnych kryteriów konwergencji ustalone w TofUE ${ }^{21}$. Dlatego dodatkowe wprowadzenie w europejskim prawie finansowym uregulowań dotyczących krajowych regul fiskalnych, a szczególnie obowiązku ich uwzględniania przy opracowaniu budżetu danego państwa, należy ocenić pozytywnie. W ten sposób już na szczeblu krajowym zostaną wdrożone normatywne ograniczenia dotyczące polityki budżetowej, które powinny sprzyjać wypełnianiu przez państwa UE ponadnarodowych reguł fiskalnych, którymi są fiskalne kryteria konwergencji.

\section{NOWE RAMY INSTYTUCJONALNE NADZORU MAKROEKONOMICZNEGO}

Konsekwencją kryzysu gospodarczego jest poszukiwanie kompleksowych rozwiązań legislacyjnych, które będą mogły w przyszłości zabezpieczyć państwa UE przed niekontrolowanym narastaniem długu i deficytu publicznego, a także przygotować instrumenty polityki gospodarczej o charakterze antykryzysowym. Ponieważ, jak wcześniej wskazano, przyczyny projektowanych zmian legislacyjnych mają charakter ekonomiczny, w propozycjach reformy uwzględniono także rozwiązania legislacyjne, które mają na celu wzmocnienie nadzoru nad polityką makroekonomiczną państw UE. W tym kontekście pozytywnie należy ocenić nowe podejście do analizy zakłóceń makroekonomicznych w państwach UE, która ma być dokonywana również $\mathrm{z}$ uwzględnieniem polityki budżetowej oraz reform strukturalnych stymulujących wzrost gospodarczy w tych państwach. W celu zdyscyplinowania państw UE do przestrzegania nowych regulacji ustalono zestaw normatywnych sankcji ${ }^{22}$.

20 W piśmiennictwie wskazuje się bowiem, że ,cele zapisane w średnioterminowych ramach budżetowych stanowią słabszą formę zaangażowania narzędzi budżetowych niż czyste reguły fiskalne", S. Franek, Średnioterminowe ramy budżetowe jako narzędzie wieloletniego planowania finansowego, [w:] Dylematy i wyzwania finansów publicznych, red. T. Juja, Zeszyty Naukowe Uniwersytetu Ekonomicznego w Poznaniu 2010, nr 141, s. 142.

21 Fiscal rules - anchoring expectations from sustainable public finances, approved by C. Cottarelli, IMF, 2009, www.imf.org/external/np/pp/eng/2009/121609.pdf (data dostępu: 25.03.2011 r.), s. $32 \mathrm{i} \mathrm{n.}$

22 Wniosek Rozporzqdzenie Parlamentu Europejskiego i Rady w sprawie środków egzekwowania korekty nadmiernych zaburzeń równowagi makroekonomicznej w strefie euro, $\mathrm{KOM}(2010)$ 525, Bruksela, 29.09.2010 r., s. 3 i n. 
Nowe ramy nadzoru makroekonomicznego zostały ujęte w projektach dwóch aktów prawnych. W pierwszym $\mathrm{z}$ nich ${ }^{23}$ unormowano nowy instrument nadzoru gospodarczego, którym ma być procedura nadmiernego zaburzenia równowagi. Nadmiernym zaburzeniem równowagi jest poważne zaburzenie równowagi, tj. taki rozwój sytuacji makroekonomicznej, który ma lub może mieć niekorzystny wpływ na prawidłowe funkcjonowanie gospodarki państwa UE lub UGW, lub całej UE, w tym zaburzenie zagrażające prawidłowemu funkcjonowaniu UGW. W ramach tej procedury ma zostać opracowany mechanizm ostrzegania, oparty na identyfikacji zaburzeń równowagi makroekonomicznej ustalonych na podstawie tabeli wskaźników makroekonomicznych, skonstruowanych dla każdego z państw UE ze wskazaniem progów alarmowych. Jeżeli państwo UE będzie zagrożone ryzykiem zaburzenia równowagi, będą podejmowane dalsze działania dyscyplinujące, włącznie ze stwierdzeniem na podstawie art. 121 ust. 4 TofUE o wszczęciu procedury nadmiernego zaburzenia równowagi. Jeżeli kolejne działania w ramach tej procedury nie okażą się skuteczne, to na państwa strefy euro będzie można nałożyć sankcję określoną w kolejnym projektowanym rozporządzeniu ${ }^{24}$, tj. roczną grzywnę wynoszącą $0,1 \%$ PKB państwa w poprzednim roku. Istnieje możliwość anulowania albo zmniejszenia jej wysokości (m.in. jeżeli w państwie UGW wystąpiła wyjątkowa sytuacja gospodarcza ${ }^{25}$ ).

\section{ZAKOŃCZENIE}

Projektowane zmiany europejskiego prawa finansowego należy ocenić pozytywnie. Trzeba przede wszystkim zaakcentować ich kompleksowy charakter, wyrażający się, po pierwsze, w uwzględnianiu zagadnień prawno-ekonomicznych oraz, po drugie, w jednoczesnym podejściu prewencyjnym i korekcyjnym do regulowanej materii.

W projektowanej reformie zarządzania gospodarczego w UE planuje się wprowadzić nie tylko regulacje dotyczące wzmocnienia ram instytucjonalnych polityki budżetowej, ale również dotyczące aspektów nierównowagi makroekonomicznej, co w konsekwencji powinno przyczynić się do sukcesu wprowadza-

\footnotetext{
23 Wniosek Rozporzadzenie Parlamentu Europejskiego i Rady w sprawie zapobiegania zaburzeniom równowagi makroekonomicznej i ich korygowania, KOM(2010) 527, Bruksela, 29.09.2010 r.

${ }^{24}$ Wniosek Rozporzadzenie Parlamentu Europejskiego i Rady w sprawie środków egzekwowania korekty.

${ }_{25}$ Wyjątkowa sytuacja gospodarcza oznacza sytuację, w której przekroczenie przez deficyt publiczny wartości referencyjnej uznaje się za wyjątkowe w rozumieniu art. 126 ust. 2 lit. a) tiret drugie TofUE i rozporządzenia Rady (WE) nr 1467/97.
} 
nych reform, tj. skutecznego ograniczenia wzrostu deficytu i długu publicznego w państwach UE.

Równie pozytywnie należy ocenić zabiegi legislacyjne służące wzmocnieniu PSW. Po pierwsze, w ramach części prewencyjnej PSW doprecyzowano zasadę rozważnej polityki budżetowej przez powiązanie rocznego tempa wydatków ze wzrostem PKB i osiągnięciem średnioterminowego celu budżetowego. W razie uzyskania nadzwyczajnych dochodów powinny one przede wszystkim służyć spłacie długu publicznego, a nie zostać przeznaczone np. na wydatki o charakterze konsumpcyjnym. Po drugie, w ramach części naprawczej PSW doprecyzowano kryterium długu publicznego w procedurze nadmiernego deficytu przez wprowadzenie liczbowej wartości referencyjnej. W ten sposób jednoznacznie będzie można ocenić, czy w danym państwie UE relacja długu do PKB, która przekracza $60 \%$, obniża się w zadowalającym tempie. Pozwoli to zastosować w tym względzie jednolite kryteria oceny do wszystkich państw UE.

$\mathrm{Na}$ uwagę zasługuje również kolejna proponowana zmiana, tj. wprowadzenie dodatkowych numerycznych reguł fiskalnych na szczeblu krajowym, będących uzupełnieniem ponadnarodowych fiskalnych kryteriów konwergencji dotyczących długu i deficytu publicznego. W konsekwencji stosunkowo wcześnie, już bowiem w ramach krajowej polityki budżetowej, powinny zostać wszczęte odpowiednie działania zaradcze, które powinny przyczyniać się do spełniania przez państwo UE fiskalnych kryteriów konwergencji.

Należy podkreślić, że projektowane zmiany, oprócz dotychczasowego trendu związanego $\mathrm{z}$ ramami budżetowymi, wprowadzają nowe instytucjonalne rozwiązania nadzoru nad zarządzaniem gospodarczym w UE, które dotyczą wykrywania, przeciwdziałania i korekty nierównowagi makroekonomicznej. Jest to działanie jak najbardziej pożądane, ponieważ pozwala na kompleksowe przeciwdziałanie przyczynom wzrostu długu i deficytu publicznego, które mogą mieć swoje źródło m.in. w sytuacji makroekonomicznej danego państwa.

$\mathrm{Na}$ podkreślenie zasługuje również, iż analizowana reforma zarządzania gospodarczego w UE ma służyć jak najwcześniejszemu wykrywaniu zaburzeń, zarówno w finansach publicznych danego państwa UE, jak i zaburzeń sytuacji makroekonomicznej. W ten sposób stosunkowo wcześnie powinny zostać wdrożone instrumenty i procedury nadzorcze, które powinny oddalić ryzyko pogłębienia tych niekorzystnych tendencji. Na uwagę zasługuje również wzmocnienie instrumentów o charakterze sanacyjnym, które mogą zostać nałożone na państwo UE lub UGW, które nie podejmuje stosownych działań korekcyjnych np. w ramach projektowanej procedury nadmiernego zaburzenia równowagi makroekonomicznej. Należy podkreślić, że nadmiernym zaburzeniem równowagi jest taki rozwój sytuacji makroekonomicznej, który ma lub może mieć niekorzystny wpływ na prawidłowe funkcjonowanie gospodarki państwa UE lub UGW, lub całej UE - 
a zatem przedmiotem ochrony jest stabilność gospodarcza zarówno poszczególnych państw UE, jak i całej UE.

\section{BIBLIOGRAFIA}

European semester: a new architecture for the new EU Economic governance, $\mathrm{MEMO} / 11 / 14$, Brussels, 12.01.2011 r.

Fiscal rules - anchoring expectations from sustainable public finances, approved by C. Cottarelli, IMF, 2009.

Franek S., Średnioterminowe ramy budżetowe jako narzędzie wieloletniego planowania $f-$ nansowego, [w:] Dylematy i wyzwania finansów publicznych, red. T. Juja, Zeszyty Naukowe Uniwersytetu Ekonomicznego w Poznaniu, nr 141, Poznań 2010.

Jajko B., Dtug publiczny a równowaga fiskalna, Warszawa 2008.

Komunikat Komisji do Parlamentu Europejskiego, Rady, Europejskiego Komitetu Ekonomicznego-Spotecznego i Komitetu Regionów, Roczna wizja wzrostu gospodarczego: wsparcie catościowej odpowiedzi UE na kryzys, Bruksela, 12.01.2011 r.

Komunikat Komisji Europa 2020, Strategia na rzecz inteligentnego $i$ zrównoważonego rozwoju sprzyjajacego wtaczeniu spotecznemu, $\mathrm{KOM}(2010)$ 2020, Bruksela, 3.3.2010 r.

Marchewka-Bartkowiak K., Problem dtugu publicznego w Unii Europejskiej ze szczególnym uwzględnieniem kryteriów z Maastricht, [w:] Polityka budżetowa, red. G. Gołębiowski, Studia Biura Analiz Sejmowych 2010, nr 3.

„PF - Monitor konwergencji nominalnej w UE 27”, Ministerstwo Finansów 2011, nr 3.

Roczne sprawozdanie gospodarcze. Zatacznik 2. Sprawozdanie makroekonomiczne, $\operatorname{KOM}(2011)$ 11, Bruksela 12.01.2011 r.

Rozporządzenie Rady (WE) z dnia 7 lipca 1997 r. Nr 1467/97 w sprawie przyspieszenia i wyjaśnienia procedury nadmiernego deficytu (Dz. U. UE.L. z 1997/209/6 ze zmianami: Dz.U.UE-sp.10/1/89, Dz. U. UE L. z 2005/174/5).

Rozporządzenie Rady (WE) z dnia 7 lipca 1997 r. nr 1466/97 mające na celu wzmocnienie nadzoru nad sytuacją budżetową oraz nadzoru i koordynacji polityk gospodarczych (Dz.U. UE L 209 z 2/8/1997).

Uchwała Rady Europejskiej z dnia 17 czerwca 1997 r. (Dz. U. UE C 236 z 2/8/1997).

Traktat o funkcjonowaniu Unii Europejskiej - wersja skonsolidowana (Dz. Urz. UE C 115 z 9.5.2005 r., s. 47).

Wniosek Dyrektywa Rady w sprawie wymogów dotyczacych ram budżetowych w państwach cztonkowskich, $\operatorname{KOM(2010)~523,~Bruksela,~29.09.2010~r.~}$

Wniosek Rozporzadzenie Parlamentu Europejskiego i Rady w sprawie środków egzekwowania korekty nadmiernych zaburzeń równowagi makroekonomicznej w strefie euro, $\mathrm{KOM}(2010)$ 525, Bruksela, 29.09.2010 r.

Wniosek Rozporzadzenie Parlamentu Europejskiego i Rady w sprawie zapobiegania zaburzeniom równowagi makroekonomicznej i ich korygowania, $\operatorname{KOM}(2010)$ 527, Bruksela, 29.09.2010 r. 
Wniosek Rozporzadzenie Parlamentu Europejskiego i Rady w sprawie skutecznego egzekwowania nadzoru budżetowego w strefie euro, $\operatorname{KOM(2010)~524,~Bruksela,~29.09.2010~r.~}$

Wniosek Rozporzqdzenie Rady zmieniajace rozporzqdzenie (WE) nr 1467/97 w sprawie przyspieszenia $i$ wyjaśnienia procedury nadmiernego deficytu, $\mathrm{KOM}(2010)$ 522, Bruksela, 29.09.2010 r.

Wniosek Rozporzadzenie Parlamentu Europejskiego i Rady zmieniajace rozporzadzenie (WE) nr 1466/97 w sprawie wzmocnienia nadzoru pozycji budzetowych oraz nadzoru $i$ koordynacji polityk gospodarczych, KOM(2010) 526, Bruksela, 29.09.2010 r.

\section{THE BASIC ASSUMPTIONS OF THE REFORM OF EUROPEAN FINANCIAL LAW AIMED AT LIMITING THE GROWTH OF PUBLIC DEBT AND DEFICIT} SUMMARY

The aim of this paper is to analyze the planned changes in European financial law, whose purpose is to restore balance and control over the public finances of Member States of the European Union. The problem of rising debt among EU countries made it necessary to review existing and new regulations seeking to strengthen control over the level of public debt, the pace of its growth and the causes of this phenomenon. Accordingly, at EU level, particularly in the countries of the Economic and Monetary Union, reform of economic governance is to be implemented, the elements of which are also covered related to the strengthening of supervision of EU budgetary policy (e.g. strengthening Stability and Growth Pact, measures taken to detect, prevent and correct macroeconomic imbalance. 